\title{
ARCHIMEDES' SPIRAL — HISTORY AND MODERNITY
}

\author{
A. Vorobiova, G. Tsygankova \\ National University of Food Technologies
}

\begin{tabular}{l} 
Key words: \\
Line \\
Flat curve line \\
Spiral \\
Spiral shapes \\
\hline \multicolumn{1}{c}{ Article history: } \\
Received 15.01.2018 \\
Received in revised form \\
24.01.2018 \\
Accepted 14.02.2018 \\
\hline
\end{tabular}

Corresponding author:

A. Vorobiova

E-mail:

npnuht@ukr.net

\begin{abstract}
In this article there are questions about the history of development of flat curved lines, spiral shapes, which have wide distribution in the nature. Spirals as mathematical objects were studied by outstanding mathematicians of the past, such as Archimedes, Bernoulli, Fermat and others. Spiral form includes symmetry and golden ratio, produces the feelings of harmony and beauty. Flat and spatial curve lines, which include generalized Archimedes spirals, chain lines, lituums, cycloids, and others are a great and interesting class. The main property of the Archimedes spirals is as follows: whatever the point of this spiral, the ratio of its radius vector to the polar angle, which is deducted from any fixed direction, will be the same.

There are spirals in different types of human activity: mechanics, engineering and food industry. The formation of the Archimedes spirals and the way of constructing it without a formula, namely by dividing the circle by a large number of radial lines with the same angles between them, as well as by a large number of concentric circles are analyzed in this article. Knowledge about the properties and graphs of generalized Archimedes spirals is systematized. Using the differential and integral calculus, the length of the first coil of the Archimedes spiral and the area bounded by the Archimedes spiral $r=a \varphi$ and two radius vectors corresponding to the polar angles $\varphi_{1}$ and $\varphi_{2}$ are found.

Spiral shapes in nature are manifested in three basic forms: static (shells of snails), expanding shapes (images of spiral galaxies) or compressible (like a whirlpool). Spiral forms are represented from the evolutionary depths (DNA molecules) to the laws of dialectics. The shape of the spiral is close to the circle - the most ideal form of all that nature has created. Spiral curves are used for many technical calculations, and knowledge about these curves facilitates the study of machine parts. Properties of cycloid curves are used in the construction of gear teeth profiles and in many other technical issues. An analysis of the use of spiral structures in nature, technology, plant and animal world, human life has been made.
\end{abstract}

DOI: $10.24263 / 2225-2924-2018-24-1-23$ 


\title{
СПІРАЛЬ АРХІМЕДА - ІСТОРІЯ І СУЧАСНІСТЬ
}

\author{
А.М. Воробйова, Г.А. Циганкова \\ Національний університет харчових технологій
}

У статті розглянуто питання з історії розвитку плоских кривих ліній, спіралеподібних форм, щуо дуже поширені в природі. Спіралі як математичні об'єкти досліджували такі видатні математики минулого, як Архімед, Бернуллі, Ферма та інші. Форма спіралі поєднує в собі симетрію $і$ золотий перетин, викликає відчуття гармонії $i$ краси. Великий $i$ иікавий клас складають плоскі та просторові криві лінії, до яких належать узагальнені спіралі Архімеда, ланцюгова лінія, літуус, циклоїда тощо. Основна властивість спіралі Архімеда полягає в тому, що яку б точку иүієї спіралі ми не взяли, відношення ї̈ радіус-вектора до полярного кута, який відраховується від будь-якого фіксованого напрямку, буде одним і тим же. Зустрічаються спіралі і в різних галузях діяльності людини: в механіці, техніці, харчовій промисловості. Проаналізовано утворення спіралі Архімеда і спосіб побудови іï без формули, а саме: поділом кола великою кількістю радіальних ліній $з$ рівними кутами між ними, а також великою кількістю концентричних кіл. Систематизовано знання про властивості і графіки узагальнених спіралей Архімеда. За допомогою диференціального та інтегрального числення знайдено довжину першого витка спіралі Архімеда і площу, обмежену спіраллю Архімеда $r=a \varphi$ і двома радіус-векторами, які відповідають полярними кутам $\varphi_{1} i \varphi_{2}$.

Спіралеподібні форми у природі проявляються в трьох основних формах: застиглій (раковини равликів), формі, щзо розиирюється (зображення спіральних галактик), або стискальній (подоба виру). Спіральні форми представлені від еволючійних глибин (молекули ДНК) до законів діалектики. Форма спіралі близька до кола - найідеальнішої форми з усіх, щзо створила природа. Спіральні криві застосовуються при багатьох технічних розрахунках, $i$ знання цих кривих полегшує вивчення деталей машин. Властивостями ичиклоїдальних кривих користуються при побудові профілів зубців шестерень $i$ в багатьох інших технічних питаннях. Проведено аналіз використання спіралеподібних структур в природі, техніці, рослинному й тваринному світі, житті людини.

Ключові слова: лінія, плоска крива, спіраль, спіралеподібні форми.

Постановка проблеми. Форму спіралі має велика кількість об'єктів у природі: як нескінченно великі об'єкти - галактики, так і малі — повітряні вихори та смерчі, зовнішня форма раковини равлика, вир, що утворюється при спуску води в отвір ванни, тощо. В атмосфері Землі існує багато явищ, пов'язаних із хвильовими та вихровими спіральними рухами частинок. Це стосується, наприклад, руху повітря в тайфунах, атмосферних синоптичних вихорах-циклонах, антициклонах тощо. Зустрічаються спіралі і в різних галузях, пов'язаних із діяльністю людини: в гідротехніці при створення труб 
для підводу води до турбіни, у механіці (кулачковий механізм, годинниковий механізм), у харчовій промисловості (гвинтовий ротор у машинах для перемішування рідких, сипучих, тістоподібних матеріалів, м'ясорубці, ножі для нарізки різних овочів). Сьогодні визначають, наприклад, спіральний цикл життя програмного продукту, спіральні моделі взаємодії системи підприємств. Історики говорять про спіральний хід історії [1]. Спіралі як математичні об'єкти досліджували такі видатні математики минулого, як Архімед, Бернуллі, Ферма та інші. Серед найпоширеніших кривих, що мають відображення у природі (циклоїда, епіциклоїда, еліпс, коло тощо), важливе місце займає спіраль Архімеда.

Метою статті $є$ дослідження й обгрунтування властивостей спіралі Архімеда в природі та у практичній діяльності людини, можливості використання іiі для математичного моделювання морфологічної структури природних об'єктів.

3 огляду на поставлену мету практичними завданнями дослідження $\epsilon$ ознайомлення $з$ внеском учених-математиків світу у розвиток вчення про криві лінії; систематизація знань про спіраль Архімеда та іï властивості; дослідження знаходження довжини дуги та площі спіралі; аналіз використання спіралі Архімеда в природі та житті людини.

Викладення основних результатів дослідження. Поняття лінії визначилося в людини в доісторичні часи. Траєкторія кинутого каменю, струмінь води, промені світла, обриси кольорів і листя рослин, звивиста лінія берега річки та інші явища природи привертали увагу наших предків. Проте знадобився великий історичний період для того, щоб люди стали порівнювати між собою форми кривих ліній і відрізняти одну криву від іншої. Але все це було ще далеке до того абстрактного розуміння лінії, що має математика зараз. Вчення про лінії стало розвиватися 3 появою математики як науки. Найвищого рівня воно досягло в працях грецьких математиків.

Грецькі вчені створили теорію конічних перетинів — ліній, які мають особливо велике значення в науці і техніці. Відкриття їх приписується Менехму, учителю Олександра Македонського [2].

Давньогрецький учений Архімед (287-212 р. до н. е.) із Сиракуз (Сицилія) працював у галузі математики, фізики, механіки, астрономії. Архімед був видатним інженером-винахідником. Він винайшов гвинтовий насос для викачування води, так звану кохлею, який широко застосовується і зараз у техніці та в побуті. Гвинтова авіація, гвинтові кораблі, турбіни, різні види шнеків, шнекові преси, гвинтові насоси, вентилятори та багато інших приладів, механізмів і знарядь $\epsilon$ нащадками архімедового гвинта. Архімед розробив системи для підняття вантажів, визначення складу сплавів зважуванням у воді. Він брав безпосередню участь у підготовці оборонних споруд, створенні воєнних метальних машин.

До нас дійшло дев'ять праць Архімеда, а саме: «Про кулю і циліндр», «Про вимірювання круга», «Про коноїди і сфероїди», «Про спіралі», «Про рівновагу площин», «Про число піщинок», «Про квадратуру параболи», «Про плаваючі тіла» і «Леми». Частина праць Архімеда втрачена. 3 висловлювань деяких авторів і самого Архімеда можна зробити висновок, що до нас не дійшли такі твори: «Про основи лічби», «Про многогранники», «Про терези», 
«Про важелі». Не збереглися твори Архімеда з оптики й астрономії, а також його міркування про календар.

Найкращим другом Архімеда був астроном Конон Самоський. Архімед досліджував спіральні лінії, які були відкриті Кононом. Криві цього виду мають назву архімедових спіралей, бо саме Архімед відкрив і довів найголовніші їхні властивості.

За однією 3 версій Архімед відкрив свою спіраль, експериментуючи 3 компасом. Він тягнув стрілку компаса 3 постійною швидкістю, обертаючи сам компас за годинниковою стрілкою. Крива, яка утворилася, була спіраллю. Крива зсувалася на ту ж величину, на яку повертався компас, а між витками спіралі зберігалася одна і та ж відстань.

Творчість Архімеда становить цілу епоху в розвитку математики взагалі. Архімед, створивши метод вичерпування, зробив великий внесок у ту галузь математики, що зараз займається аналізом нескінченно малих величин. Його праці стали першоосновою для успішного подальшого розвитку математики в дослідженнях Ньютона, Лейбніца та інших математиків XVII ст. у галузі диференціального та інтегрального числень.

Спіраль Архімеда - це крива, яку описує точка М під час іiі рівномірного руху зі швидкістю $v$ уздовж прямої, що рівномірно обертається в площині навколо однісї зі своїх точок $O$ з кутовою швидкістю $\omega$. Основна властивість спіралі Архімеда полягає в тому, що, яку б точку цієї спіралі ми не взяли, відношення iї радіус-вектора до полярного кута (який відраховується від будь-якого фіксованого напрямку) буде одним і тим же. Якщо в початковий момент руху точки $M$ і $O$ збігаються, а полярна вісь збігається 3 початковим розташуванням рухомої прямої, то рівняння спіралі Архімеда має вигляд $\rho=a \omega$. Будь-який радіус-вектор зустрічає криву незліченну кількість разів, до того ж відстань між кожними двома послідовними точками перетину $є$ величина постійна $-2 a \pi$ ( рис. 1$)$.

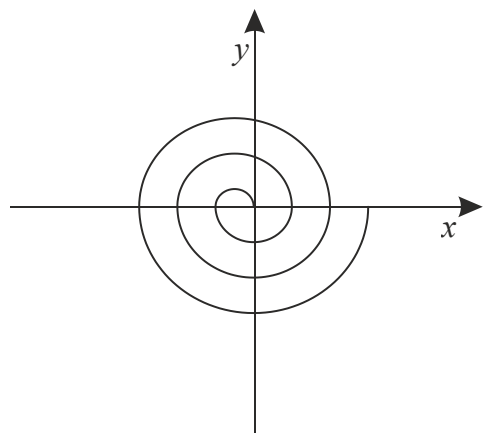

Рис. 1. Спіраль Архімеда

Одним із найбільш простих способів побудови спіралі Архімеда без формули $є$ поділ кола великою кількістю радіанних ліній з рівними кутами між ними, а також великою кількістю концентричних кіл.

Із центра $O$ (рис. 2) опишемо коло радіусом $R=a$. Відрізок $O A$ та коло поділимо на однакову кількість рівних частин, наприклад, на вісім. Побу- 
дуємо концентричні кола з центром в точці $O$ і радіусами $O 1, O 2, O 3, O 4, \ldots$, $O 8$ та промені $O 1_{1}, O 2_{1}, O 3_{1}, \ldots, O 8_{1}$, проведені через центр $O$ і відповідні точки поділу кола $1_{1}, 2,3_{1}, \ldots, 8_{1}$. Точки $A_{1}, A_{2}, A_{3}, \ldots, A_{8}$ перетинів концентричних кіл і променів будуть точками спіралі. Якщо з'єднати ці точки неперервною лінією, то отримаємо спіраль Архімеда.

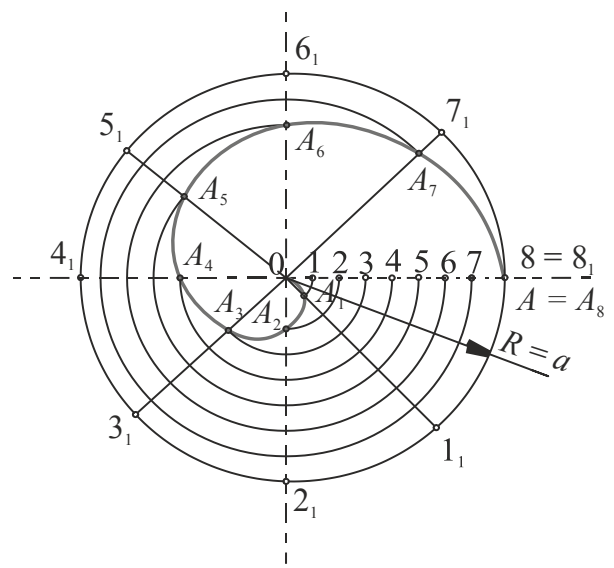

Рис. 2. Побудова спіралі Архімеда

Але розділити коло на більше ніж 12 секторів - нетривіальна задача. Спіраль Архімеда є частинним випадком при $n=1$ узагальненої спіралі Архімеда, рівняння якої в полярних координатах визначається: $r=b+a \theta^{1 / n}$ (в подальшому $b=0$ ). При значенні $n=-1$ отримаємо гіперболічну спіраль, при $n=2$ - спіраль Ферма, при $n=-2$ - літуус (жезл).

Знайдемо площу, обмежену спіраллю Архімеда, $r=a \varphi$ і двома радіусамивекторами, які відповідають полярним кутам $\varphi_{1}$ i $\varphi_{2}\left(\varphi_{1}<\varphi_{2}\right)$.

Для цього потрібно скористатися формулою для знаходження площі $S=\frac{1}{2} \int_{\alpha}^{\beta} r^{2} d \varphi$, де $\alpha$ і $\beta$ - межі зміни полярного кута [3]. Таким чином, отримуємо:

$$
S=\frac{1}{2} \int_{\varphi_{1}}^{\varphi_{2}} a^{2} \varphi^{2} d \varphi=\left.\frac{1}{2} a^{2} \frac{\varphi^{3}}{3}\right|_{\varphi_{1}} ^{\varphi_{2}}=\frac{a^{2}\left(\varphi_{2}^{3}-\varphi_{1}^{3}\right)}{6} .
$$

Тоді площа, обмежена полярною віссю і першим витком спіралі Архімеда $\left(\varphi_{1}=0 ; \varphi_{2}=2 \pi\right)$, знаходиться так: $S_{1}=\frac{a^{2}}{6}(2 \pi)^{2}=\frac{4}{3} \pi^{3} a^{2}$.

Аналогічним чином знаходимо площу, обмежену полярною віссю і другим витком спіралі Архімеда $\left(\varphi_{1}=2 \pi ; \varphi_{2}=4 \pi\right)$ :

$$
S_{2}=\frac{a^{2}}{6}\left(64 \pi^{2}-8 \pi^{3}\right)=\frac{56}{6} \pi^{3} a^{2}=\frac{28}{3} \pi^{3} a^{2} .
$$


Шукана площа дорівнює різниці цих площ:

$$
S_{2}-S_{1}=\frac{28}{3} \pi^{3} a^{2}-\frac{4}{3} \pi^{3} a^{2}=8 \pi^{3} a^{2} .
$$

Проаналізуємо, як знайти довжину першого витка спіралі Архімеда $r=\varphi$.

Кінці першого витка відповідають значенням $\varphi_{1}=0 ; \varphi_{2}=2 \pi$ і полярного кута ф. Скористаємось формулою для знаходження довжини дуги

$$
L=\int_{\alpha}^{\beta} \sqrt{r^{2}(\varphi)+\left(r^{\prime}(\varphi)\right)^{2}} d \varphi .
$$

У нашому випадку $r=\varphi \Rightarrow r^{\prime}=1$. Тоді $L=\int_{0}^{2 \pi} \sqrt{1+\varphi^{2}} d \varphi$.

Інтегруємо частинами. Позначимо $u=\sqrt{1+\varphi^{2}}, d v=d \varphi$. Тоді $d u=\frac{\varphi}{\sqrt{1+\varphi^{2}}} d \varphi$, $v=\varphi$. Довжина дуги знаходиться:

$$
\begin{gathered}
L=\left.\varphi \sqrt{1+\varphi^{2}}\right|_{0} ^{2 \pi}-\int_{0}^{2 \pi} \frac{\varphi^{2}}{\sqrt{1+\varphi^{2}}} d \varphi= \\
=2 \pi \sqrt{1+4 \pi^{2}}-\int_{0}^{2 \pi} \sqrt{1+\varphi^{2}} d \varphi+\int_{0}^{2 \pi} \frac{d \varphi}{\sqrt{1+\varphi^{2}}}= \\
=2 \pi \sqrt{1+4 \pi^{2}}-L+\left.\ln \left(\varphi+\sqrt{1+\varphi^{2}}\right)\right|_{0} ^{2 \pi}= \\
=2 \pi \sqrt{1+4 \pi^{2}}-L+\ln \left(2 \pi+\sqrt{1+4 \pi^{2}}\right)
\end{gathered}
$$

Звідки

$$
L=\pi \sqrt{1+4 \pi^{2}}+\frac{1}{2} \ln \left(2 \pi+\sqrt{1+4 \pi^{2}}\right) .
$$

Отже, за допомогою диференціального та інтегрального числення можна знайти довжину дуги першого витка спіралі Архімеда і площу, обмежену спіраллю Архімеда $r=a \varphi$ та двома радіус-векторами, які відповідають полярним кутам $\varphi_{1}$ i $\varphi_{2}\left(\varphi_{1}<\varphi_{2}\right)$.

Елементи, що мають форму спіралі, дуже поширені в природі [5]. Вигляд спіралі близький до кола - найідеальнішої форми 3 усіх, що створила природа. Спіраль Архімеда має тісний зв'язок із послідовністю Фібоначчі математичним числовим рядом, кожен член якого є сумою двох попередніх. Закон математики описує принцип спіралі Архімеда і золотого перетину: границя відношення двох послідовних чисел із ряду Фібоначчі - більшого на менше - дорівнює $\approx 1,618$ тим точніше, чим більші члени послідов-ності [4]. У природі послідовність Фібоначчі можна прослідкувати на прикладах спірального розвитку зернят соняшника та інших квітів. Наприклад, суцвіття соняшника складається зі спіралей Архімеда, одна 3 них закручена за 
годинниковою стрілкою, а друга - проти. Причому у суцвітті соняшника середнього розміру за підрахунками 34 спіралі одного напрямку і 55 іншого, у суцвітті ромашки — 34 спіралі одного напрямку і 21 - іншого. Числа 34, 21, 55 - це числа ряду Фібоначчі. Соснова шишка, алое багатолистий, броколі романеско — це приклади рослин, які складаються зі спіралей Архімеда. Спіраллю Архімеда представлені в рослинному світі і видозміни листків, тобто вусики рослин, якими вони чіпляються за різні предмети і закріплюють стебло в певному положенні (горох, виноград, огірок).

I хоча в тваринному світі спіраль Архімеда трапляється не так часто, мушлі багатьох молюсків мають іiі форму. Роги таких тварин, як архари (гірські козли), закручені спіраллю Архімеда. Кігті лева, дзюби папуг являють собою спіральні форми, нагадують форму осі, що може перетворитися в спіраль.

Спіраль Архімеда також широко використовується в техніці. Один із винаходів ученого - гвинт (прообраз об'ємної спіралі) - покладений в основу механізму для передачі води в зрошувальні канали з низьколежачих водойм. Гвинт Архімеда став прообразом шнека — пристрою, що широко використовується в різних машинах для перемішування рідких, сипучих i тістоподібних матеріалів. Найпоширеніший його різновид - гвинтовий ротор у звичайній м'ясорубці. Іще один об'єкт, який працює за допомогою спіралі Архімеда, - це самоцентруючий патрон, спрямовуючі канавки якого виконані за спіраллю Архімеда. При одному повороті диска цього патрона кулачки переміщаються на величину радіальної відстані суміжних канавок. Цей механізм використовується у швейних машинках для рівномірного намотування ниток. Механізми з елементами у формі спіралі використовуються і в харчових виробництвах. Наприклад, ножі для довгої нарізки капусти виготовляються у вигляді спіралі Архімеда (рис. 3).

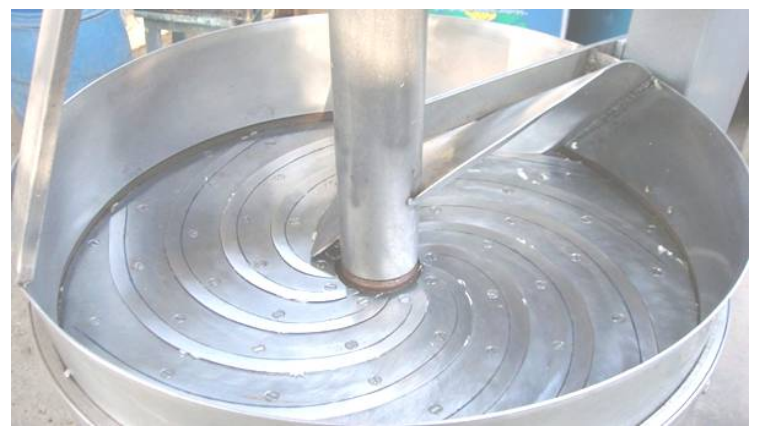

Рис. 3. Ніж для нарізки капусти

Вражає надзвичайна різноманітність значень символу спіралі. Ще здавна люди використовували іï як декоративний символ, візерунок, який легко наноситься на дерево, каміння, глину. Форма спіралі поєднує в собі симетрію і золотий перетин, при зоровому сприйнятті вона викликає відчуття гармонії $\mathrm{i}$ краси. Спіраль вважається знаком розвитку, життєвої сили, даної нам природою. Це прагнення до нових рівнів, до свого центру, мудрості. Спіральний символ часто зустрічається і в мистецтві, де символізує гармонію, красу, 
розвиток. У практиці традиційної архітектури спіраль виникає не часто, але залишає значний слід або фіксує певні етапи розвитку архітектури. Відома, наприклад, спіралеподібна мечеть у Самарі, капітелі іонічних колон у Древній Греції. Спіраллю Архімеда ще в давнину оздоблювали жіночі прикраси. Наприклад, скіфська пектораль (шийна прикраса, що закривала груди, часом $\mathrm{i}$ плечі), яка була виявлена у 1971 р. видатним українським археологом Борисом Мозолевським. I в наш час у жінок прикраси, які мають вигляд спіралі Архімеда, користуються великою популярністю.

Найбільше утворення 3 усіх спіралеподібних форм у природі - це спіралеподібні галактики. Їхні діаметри вимірюються тисячами світлових років. Галактика Чумацький Шлях, у якій розміщена наша Сонячна система, та всі зорі, які ми бачимо неозброєним оком, мають форму спіралі Архімеда. Галактика Феєрверк, відкрита 9 вересня 1798 року Вільямом Гершельом, знаходиться на відстані 22 мільйонів світлових років у сузір'ї Лебідь і нагадує форму спіралі. Галактика Цівочне Колесо - спіральна галактика в сузір'ї Велика Ведмедиця. Галактика Вир - галактика в сузір'ї Пси, яка знаходиться на відстані 23 мільйонів світлових років від Землі.

\section{Висновки}

Плоскі та просторові криві лінії становлять великий і цікавий клас математичних кривих. До них належать узагальнені спіралі Архімеда (спіраль Ферма, літуус, гіперболічна спіраль) і власне спіраль Архімеда. В статті систематизовано знання про властивості і графіки спіралей Архімеда. Досліджено знаходження довжини дуги і площі спіралі Архімеда та проведено аналіз іiі використання в природі та житті людини.

\section{Лiтература}

1. Спіраль Архімеда та іï прояви в навколишньому світі [Електронний ресурс]. Режим доступу : http//www.svitohlyad.com.ua.

2. Історія геометрії [Електронний ресурс]. - Режим доступу : http//www.svippt.com.ua.

3. Дубовик В.П. Вища математика: навч. посіб. / В.П. Дубовик, І.І. Юрик. - 4-е вид., перероб. і доп. — Київ : Ігнатекс-Україна, 2013. — 636 с.

4. Стахов А. Код да Винчи и ряды Фибоначчи / А. Стахов, А. Слученкова, И. Щербаков. - Санкт-Петербург : Питер, 2006. - 320 с.: ил.

5. Аракелян Г. Математика и история золотого сечения / Г. Аракелян - Москва : Логос, 2014. - $50 \mathrm{c}$. 